\title{
RESTRICTIONS ON THE ACQUISITION OF CERTAIN CATEGORIES OF REAL ESTATE IN RELATION TO THE BASIC MARKET FREEDOMS IN THE EUROPEAN UNION
}

\author{
Ivna Godžirov, LLM, PhD Candidate \\ Josip Juraj Strossmayer University of Osijek, Faculty of Law Osijek \\ Stjepana Radića 13, Osijek, Croatia \\ igodzirov@auric-oak.com
}

\begin{abstract}
The acquisition of ownership of real estate in the European Union is regulated by national laws of the Member States. As one of the cornerstones of the EU legal system is the prohibition of discrimination based on the nationality, all national systems have to allow citizens of other $E U$ Member States to acquire the ownership of real estate under the same conditions that apply to their own citizens. Nevertheless, there are certain exceptions to this rule that allow the Member States to exclude certain categories of real estate from being accessible to non-citizens, such as agricultural land, forests, secondary homes and excluded areas under special nature protection regimes.
\end{abstract}

Moreover, many States have been granted the right to transitional restrictions for the acquisition of agricultural land upon their accession to the EU, lasting for several years, during which period non-citizens were prevented from acquiring the ownership of such property. After those grace periods have ended, many countries have introduced different new measures aiming at protecting their agricultural land from being taken over by foreign investors, only by different means. Such measures, even though they are not explicitly preventing non-citizens from the acquisition of the ownership, make it practically almost impossible for them to get it.

Although the objectives behind all these practices of the Member States, such as prevention of the land-grabbing and land speculation, preserving agricultural communities and supporting the development of rural regions are quite justifiable, they still collide with basic market freedoms in the European Union.

The paper will show the multitude of legal approaches to the acquisition of real estate by non-citizens throughout the European Union. It will show the development of national policies regarding the "restricted" categories of real estate - agricultural land, forest land and land under specific protection regimes - and these national legal norms will be put in perspective with the basic freedoms of the EU internal market. The aim of the paper will be to question the 
validity and legality of such restrictions that are still in different covert forms very present on the territory of the EU Member States and offer an answer to whether such a practice presents an infringement of the internal market of the European Union.

Keywords: acquisition of real estate, restrictions of real estate acquisition, acquisition of agricultural and forest land, transitional period, basic market freedoms, discrimination on grounds of nationality

\section{INTRODUCTION}

This paper consists of four main parts. The first part starts with an overview of the existing European legislation significant for the cross-border transfer of real estate, followed by the display of fundamental freedoms of the European internal market. The second part of the paper is related to national legal frameworks on property transactions. It gives an insight into a mosaic of different restrictive measures seen in the legislation of the Member States. This part also includes a sub-chapter on transitional periods for the acquisition of agricultural land of several Member States upon their accession to the EU. Further sub-chapter presents the developments in the post-transitional periods and newly introduced measures aiming at preserving the status quo of non-nationals in the "new" Member States. The third part of the paper is dealing with reactions on the EU level to the developments in Member States. The fourth and final part of the paper explains the proportionality test, a tool for the assessment of national measures. Member States are obliged to use it to ensure that their restrictive measures are appropriate and acceptable from the viewpoint of the EU law.

The aim of this paper is not to offer an exhaustive list of all measures that could possibly lead to discrimination of non-nationals in the acquisition of ownership. The list of measures presented in the following chapters is of a merely informative character to give the reader a feeling of the variety of provisions that could be found in national legislative acts regarding this topic. The purpose of the paper is to show that the interaction between the national legal systems, that on one hand try to protect their national interests, and the European Union, that on the other hand tries to reinforce the internal market of the Union, is of a permanent character.

\section{LEGAL FRAMEWORK ON PROPERTY ACQUISITION ON THE LEVEL OF THE EUROPEAN UNION}

The first question that needs to be answered before deliberating on the property acquisition in the European Union is the question of legislative competence. One needs to distinguish between matters that fall under the competence of the EU, 
potential shared competences and those that remain in the exclusive jurisdiction of national states. The European law does not put property/ownership acquisition verbatim in any of these categories. It does, however, refer to "property ownership systems" that are explicitly excluded from the jurisdiction of the Union. The Article 345 of the Treaty on the Functioning of the European Union is the only provision regarding the subject of ownership in general in the TFEU. It reads "The Treaties shall in no way prejudice the rules in Member States governing the system of property ownership." ${ }^{1}$ Even though the current wording, purely linguistically interpreted, could suggest that, on the basis of the Article 345, the European Union does not have lawmaking competence at all in the area of ownership rights, this is not correct, and in many ways the Union still does influence the right of property of its citizens ${ }^{2}$. The expression "system of property ownership" has been controversial for decades and many scholars and practitioners have attempted to interpret the real objective of the European lawmaker behind it. The historical development shows that this article was originally limited to the ownership of undertakings ${ }^{3}$. Even though the current wording of the Article 345 is still quite ambiguous, it can be assumed that it sets down a negative competence for the EU, limited to the type of ownership (private or public) on the national market of its Member States. Hence, all other aspects of property law (including the acquisition rules) would fall in the competence of Member States as well. However, notwithstanding this Article, the EU is both actively legislating in this area and creating an impact on property law in all Member States through the practice of the Court of Justice of the European Union.

Firstly, the Union is affecting proprietary rights through its legal framework on the internal market and prohibition of discrimination ${ }^{4}$. All national property-related provisions have to be aligned with these EU norms. Secondly, EU has an extensive legal infrastructure on human rights protection that its Member States need to adhere to. The instrument for that is the Charter of Fundamental Rights of the

1 Consolidated version of the Treaty on the Functioning of the European Union, Official Journal C 326, 26.10.2012

2 The historical background of the development of the Article 345 TFEU, changes of the original wording of the article, the interpretation of its meaning and its scope of application in property law can be found here: Akkermans, B.; Ramaekers, E., Article 345 TFEU (ex Article 295 EC), Its Meanings and Interpretations, European Law Journal, vol. 16, no. 3, 2010

3 Based on the text of the Schumann declaration: «Linstitution de la Haute Autorité ne préjuge en rien du régime de propriété des entreprises. » See: Mataczyński, M., What Did the European Community Founders Actually Mean by Saying That the Treaties Shall in No Way Prejudice the Rules in Member States Governing the System of Property Ownership? Analysis of Article 345 TFEU, Adam Mieckiewicz University Law Review, vol. 4, 2014, p. 40

4 See infra, Chapter 2.1 
European Union ${ }^{5}$ that has its background in the European Convention for the Protection of the Human Rights and Fundamental Freedoms ${ }^{6}$ and its Protocol I. After the Lisbon Treaty entered into force, the Charter was granted the same legal value as the Treaties of the European Union and is together with them legally binding in all EU Member States. The Charter has reference to property in its Article 17 that affirms "everyone's right to own, use, dispose of and bequeath his lawfully acquired possessions". Furthermore, the Charter's Article 21 outlaws any discrimination based on property, among other grounds. There are other rights protected by the Charter that can be taken into consideration in regard to the acquisition of property by non-nationals, such as the freedom to choose an occupation (Article 15) and the freedom to conduct a business (Article 16). These legal norms are generally applicable in all Member States and compel them to conform to the Union's legal norms even in the domains of the exclusive national competence (such as rules on property ownership).

Such obligation of the Member States, specifically regarding the rules of property law, was repeatedly confirmed by the Court of Justice of the EU in the Fearon $v$ Irish Land Commission, Konle v the Republic of Austria ${ }^{7}$, and the more recent Essent case. Although the Court in the Konle judgment underlined that the Article 345 is "an expression of the principle of the neutrality of the Treaties" to the property rules of Member States ${ }^{8}$, it also clearly stated that "...Article 345 TFEU does not mean that rules governing the system of property ownership current in the Member States are not subject to the fundamental rules of the FEU Treaty, which rules include, inter alia, the prohibition of discrimination, freedom of establishment and the free movement of capital".?

The Union is also influencing property rights of its citizens by passing secondary legislation related to the ownership matters (increasingly in the domain of consumer protection but also regarding the sale of the new build, timesharing, energy-efficient building, mortgage finance and consumer loans) ${ }^{10}$, which aims at approximation and/or unification of law on the internal market.

Charter of Fundamental Rights of the European Union, Official Journal C 326, 26.10.2012

6 European Convention on Human Rights, Council of Europe [https://www.echr.coe.int/ Documents/ Convention_ENG.pdf], accessed on 14 March 2020

7 Case C-182/83, Fearon \& Company Limited v Irish Land Commission, ECLI:EU:C:1984:335, and case C-302/97, Konle v Republic of Austria, ECLI:EU:C:1999:271

8 Case C-105/12, Essent and Others, ECLI:EU:C:2013:677, par. 29

$9 \quad$ Ibid., par. 36

10 Mišćenić, E., Europsko privatno pravo, Opći dio, Školska knjiga, Zagreb, 2019, p. 78 
The foregoing shows that, notwithstanding the Article 345 of the TFEU and the absence of the common property law in the EU, the Union is still significantly influencing the ownership right of its citizens.

\subsection{EU fundamental freedoms and their relevance for the acquisition of property}

Cross-border real estate transactions need to serve the proper functioning of the internal market of the Union. The accomplishment of the objectives of the EU regarding the establishment of the internal market requires that cross-border real estate transactions are in principle unrestricted. Therefore, the rules on the cross-border transactions of real estate are governed by the primary and secondary EU law norms that regulate the fundamental freedoms in the EU. These are the relevant freedoms for the cross-border acquisition of ownership that are guaranteed by the Treaties: the free movement of workers (articles $45-48$ TFEU), right of establishment (articles $49-55$ ), freedom to provide services (articles 56-62) and free movement of capital (articles $63-66$ ).

All restrictions to the cross-border transfer of immovables in the Union, that would hinder the EU citizens from acquiring the property in another Member State and thus preclude them from exercising their fundamental rights as guaranteed by the Treaties, are outlawed.

How exactly are fundamental freedoms of the internal market related to the cross-border acquisition of immovables?

- Free movement of workers - as it implies the right of each EU citizen to work in another EU country and reside there, together with his/her family, and thereby be treated equally as the domestic workers, it also entails their right to have a free access to the real estate market (both as a prospective tenant and an owner);

- Freedom of establishment - in regard to real estate acquisition it presumes the absence of any restriction towards foreigners in the access to real estate and premises that are needed for the implementation of the work. It also means that on the basis of this freedom the EU citizens can request the access to the real estate for the purpose of their housing, besides the real estate for the purpose of their undertaking;

- Freedom to provide services - although Treaties do not explicitly affirm the right to real property for EU citizens who provide services in another country (while for those exercising the freedom of establishment this right is explicitly recognized), the CJEU has decided that "persons providing services cannot be 
excluded from the benefit of the fundamental principle of non-discrimination in regard to access to ownership and the use of immovable property" ${ }^{11}$; this can be also concluded from the provision of the Regulation No 492/2011 on freedom of movement for workers within the Union which in its Article 9 refers to the right of housing, including the ownership, for a worker who is a national of a Member State and employed in the territory of another Member State ${ }^{12}$;

- Free movement of capital - possibly the most relevant freedom for the cross-border real estate transactions in the European Union. This freedom applies to both intra-EU movement of capital and the movement between EU Member States and third countries ${ }^{13}$. In reference to the purchase of real estate, for the applicability of this principle it is irrelevant whether the real estate acquisition is for professional or private purposes.

Another cornerstone of the EU law is the prohibition of discrimination on the grounds of nationality (as defined in the Article 18 TFEU). The principle of non-discrimination on grounds of nationality in the area of real estate transfer applies to not only the mere eligibility to acquire real estate, but also to other procedural and side aspects of the acquisition (such as loan and subsidies eligibility, right to use the real estate etc.). This prohibition due to its subsidiary character to the market freedoms has its relevance in case when none of the market freedoms is applicable to a particular case of real estate acquisition ${ }^{14}$.

\section{NATIONAL LEGAL FRAMEWORKS ON PROPERTY ACQUISITION}

Since the EU does not have the lawmaking competence in the area of ownership rights to determine its scope and content, it is left to national states to determine the terms and conditions regarding the transfer and acquisition of real property, taking into consideration the EU legal framework ${ }^{15}$. One of the basic and oldest principles of real estate/land law is lex rei sitae, according to which every state determines the rules applicable to real property situated in $i t^{16}$. Such national

11 Case C-305/87 Commission v Greece, ECLI:EU:C:1989:218, par. 26

12 Regulation (EU) No 492/2011 of the European Parliament and of the Council of 5 April 2011 on freedom of movement for workers within the Union, Official Journal L 141/1

13 With certain exceptions as defined in the Article 64 TFEU

14 Josipović, T., Pravni promet nekretnina u Europskoj Uniji, Prilagodba hrvatskog pravnog poretka europskom, Narodne Novine, Zagreb, 2003, p. 42

15 See Case Essent, op.cit., note 8, par. 36 and Josipović, op.cit., note 14, p. 13

16 Although each country in the EU has its own set of rules in the area of real estate law, there are certain similarities between some of the systems more closely connected to the other, for historical or other 
provisions are then further intertwined with other law areas closely connected to property law, such as succession law and taxation, which creates a mosaic of as many different legal approaches to property transfer as there are Member States in the EU. However, this system, although present in every Member States of the $\mathrm{EU}$, is influenced by the obligation of the States to comply with EU rules on the internal market and prohibition of discrimination. The transfer of the real property in all EU countries is in principle characterized by contractual freedom. Yet, this freedom can be substantially influenced by different factors such as consumer protection policies, public law restrictions, tax policies, inheritance rules or state subsidies granted to the building of homes ${ }^{17}$. All these factors can potentially lead to covert discrimination and inequality of the participants on the market.

Most EU Member States put the third-country nationals in a less favourable position, making it rather difficult for them to acquire property in general, and even impossible for some categories of real estate. Usually third-country nationals can acquire real estate only under the condition of reciprocity and sometimes particular approvals from the authorities. Certain countries allow for the acquisition of real property by third-country nationals only by means of inheritance ${ }^{18}$.

When it comes to acquisition in favour of EU nationals, in the majority of EU countries there are no restrictions on the real estate acquisition, and they can acquire real estate under the same conditions as nationals of the state in question. Some countries even explicitly affirm the right to property of non-residents in their constitutions ${ }^{19}$. The Belgian Constitution, for example, grants "protection provided to persons and property for all foreigners on Belgian soil" ${ }^{20}$, as well as the Constitution of the Grand Duchy of Luxembourg ${ }^{21}$.

reasons. More on families of legal systems in comparative real estate law, see: Real Property Law and Procedure in the European Union, General Report, European University Institute (EUI) Florence / European Private Law Forum / Deutsches Notarinstitut (DNotI) Würzburg, 31.5.2005, p. 8

$17 \quad$ Ibid., p. 22

18 See the Article 22 of the Constitution of the Republic of Bulgaria, Prom. SG 56/13 Jul 1991, amend. SG 85/26 Sep 2003, SG 18/25 Feb 2005, SG 27/31 Mar 2006, SG 78/26 Sep 2006 - Constitutional Court Judgment No.7/2006, SG 12/6 Feb 2007

19 See, for example, the Constitution of the Republic of Croatia (Article 48), Official Gazette 56/90, 135/97, 08/98, 113/00, 124/00, 28/01, 41/01, 55/01, 76/10, 85/10, 05/14; the Constitution of the Republic of Slovenia (Article 68), Official Gazette RS Nos. 33/91-I, 42/97, 66/2000, 24/03, 69/04, 68/06, 47/13, and 75/16; the Constitution of Romania (Article 44), Official Gazette Part I No.233 of 21 November 1991 with the amendments in Part I, No.758 of 29 October 2003; the Constitution of the Republic of Bulgaria, op.cit. note 18, (Article 17)

20 See the Belgian Constitution (Article 191), Belgian Official Gazette of 31 January 2014 with the amendments from 29 November 2017

21 See the Constitution of the Grand Duchy of Luxembourg (Article 111), [http://www.legilux.public.lu/ eli/etat/leg/recueil/constitution/20191214], accessed on 27 March 2020 


\subsection{An overview of restrictions regarding the real estate acquisition}

On the different side, some EU countries practice restrictions in various forms. These countries mostly justify a special legal treatment of non-residents by their need to protect the national economy, in the interest of urbanistic reasons, states' defence and security strategies or to prevent the land-grabbing ${ }^{22}$ and ensure the availability of farmland for local farmers. Hence, countries overtly discriminate between residents and non-residents, either permanently for certain types of real estate (holiday homes, forests or other protected areas of land), or temporarily, based on accession treaties signed by the said state and the EU. In the last decades these restrictions have gone through many changes, primarily because of the pressure from the EU regarding the incompatibility of such measures with the internal market.

Constitutional norms in several countries contain a provision by which, on the ground of public interest, certain classes of property can be acquired only by its national $s^{23}$ or exclusively by persons domiciled in these countries ${ }^{24}$.

Apart from the constitutional norms, even legislative acts in many EU countries put restrictions on the foreigners' acquisition of certain types of real estate. The most common is the ban on the acquisition of the agricultural land ${ }^{25}$, forest land,

22 More on the phenomenon of land grabbing in European countries can be found here: Land Concentration, Land Grabbing and People's Struggles in Europe, published by the Transnational Institute for European Coordination Via Campesina and Hands Off the Land Network, June 2013, [https://www. fian.be/IMG/pdf/2013_06_Land_in_Europe-jun2013_final.pdf\#page=128], accessed on 2 April 2020

23 See for example the Estonian Constitution, Article 32, that states „On public interest grounds, the law may provide classes of property which may be acquired in Estonia only by citizens of Estonia, by certain categories of legal persons, by local authorities, or by the Estonian government." The Constitution of the Republic of Estonia, RT 1992, 26, 349, amended by RT I 2003, 29, 174, amended by RT I 2003 , 64, 429, amended by RT I 2007, 33, 210, amended by RT I, 27.04.2011

24 As is the case in the Czech Charter of Fundamental Rights and Freedoms (as a part of the constitutional order of the Czech Republic), which in its Article 11, par. 2 allows that „the law may also provide that certain items of property may be owned exclusively by citizens or legal persons with their headquarters in the Czech and Slovak Federal Republic. The similar norm can be found in the Slovak constitution, referring to „citizens or legal persons residing in the Slovak Republic“ (Article 20). The Czech Charter of Fundamental Rights and Freedoms, Ústavní zákon č. 2/1993 Sb. ve znění ústavního zákona č. 162/1998 Sb.; The Constitution of the Republic of Slovakia, Official Gazette 460/1992 Zb., 244/1998, 9/1999, 90/2001, 140/2004, 323/2004, 463/2005, 92,2006, 210/2006, 100/2010, 356/2011, 232/2012, 161/2014, 306/2014, 427/2015, 44/2017, 71/2017, 137/2017, 40/2019, 99/2019

25 See for example the Article 358.a of the Act on Ownership and Other Real Rights of the Republic of Croatia, Official Gazette 91/1996, 68/1998, 137/1999, 22/2000, 73/2000, 114/2001, 79/2006, 141/2006, 146/2008, 38/2009, 153/2009, 90/2010, 143/2012, 152/2014 
areas under special nature protection regimes ${ }^{26}$ and areas used for military purposes $^{27}$. Some countries distinguish between natural and legal foreign persons in terms of eligibility for the acquisition of certain real estate categories. Such provision can be found in the Estonian Restrictions on Acquisition of Immovables $\mathrm{Act}^{28}$ which allows the EU citizens to acquire agricultural or forest land in Estonia without restrictions, at the same time allowing the legal entities from EU countries the acquisition of a maximum of 10 hectares, unless they had been engaged in forest management or agricultural activities for longer than 3 years prior to the acquisition. This requirement can be substituted with an authorization of the local government.

Apart from described forms of a direct prohibition of acquisition for non-nationals, there are many more indirect restrictions that come in various forms ${ }^{29}$ and they can, because of their end effect, be considered as covertly discriminatory towards non-nationals. These would be, for example, legal norms allowing the transfer of real estate only to those who are domiciled in the state or a certain region, or pre-emption right in the favour of neighbours, state $^{30}$, municipalities ${ }^{31}$ or counties. Sweden, for example, requires that all natural and legal persons obtain

26 Ibid. However, since the lex specialis, the Nature Protection Act of the Republic of Croatia, Official Gazette $80 / 13,15 / 18,14 / 19,127 / 19$ does not restrict the ownership of foreigners anymore, the provision from the Act on Ownership lost its applicability

27 This is the case with Spain and its restricted military areas (all islands, Strait of Gibraltar, Portugal or France borderland) where no real estate can be acquired without a prior approval. See the land report for Spain of the European Land Registry Network: [https://www.elra.eu/contact-point-contribution/ spain/legal-restrictions-10/], accessed on 6 April 2020

28 Paragraph 4 of the Restrictions on Acquisition of Immovables Act, RT I, 23.02.2012, 11, [https://www. riigiteataja.ee/en/eli/ee/514112013013/consolide/current], accessed on 30 March 2020

29 An extensive overview of different measures in the EU countries aiming to protect the (local) owner can be found here: Swinnen, J.; Van Herck, K.; Vranken L., Land Market Regulations in Europe, LICOS Centre for Institutions and Economic Performance, KU Leuven, Discussion Paper, No. 354, p. 10 and further, [https://www.econstor.eu/bitstream/10419/126507/1/797825487.pdf], accessed on 3 April 2020

30 The Greek Law 998/1979 regulates the pre-emption right of the State before the intended sale of the private forest larger than 5 hectares. See the land report for Greece on [https://www.elra.eu/contact-point-contribution/greece/legal-restrictions-5/], accessed on 6 April 2020. The same procedure is prescribed by the Lithuanian Land Law for areas of state parks or areas under conservation, ecological protection and recreation priority, as well as areas under Natura 2000 protection, where the state has the pre-emption right to buy. See the land report for Lithuania [https://www.elra.eu/contact-point-contribution/lithuania/legal-restrictions-18/], accessed on 6 April 2020

31 For example, the Croatian Act on Protection and Preservation of Cultural Heritage in its Article 37 prescribes the pre-emption right of municipalities for the real estate in the category of cultural heritage. Act on Protection and Preservation of Cultural Heritage, Official Gazette 69/1999, 151/2003, 100/2004, 87/2009, 88/2010, 61/2011, 25/2012, 136/2012, 157/2013, 152/2014, 98/2015, 44/2017, 90/2018, $32 / 2020$ 
permission for the purchase of the agriculture land (which also includes forests), in order to control the ownership structure in the country ${ }^{32}$. Some countries set a limit on the surface above which a permit from the competent authorities is required for the purchase of (agricultural) land ${ }^{33}$. Several countries require that any foreign investment into real estate is (subsequently) reported to the authorities ${ }^{34}$. Such norms could be a form of hidden, covert discrimination of non-nationals, while they obviously can put them in a weaker position compared to the residents and thus disable foreign investments.

All abovementioned restrictions could be classified in two groups. The first group are the restrictions of a rather permanent character, prohibiting the acquisition of the real estate of certain types in general (sometimes also to residents) and unlimited in duration (such as maritime areas, military areas, areas under special nature protection regimes etc.). Some examples of such permanent exceptions to the free movement of capital are the provisions of the Treaty on the European Union (its Protocol No.32) that permits Denmark to maintain the legislation which restricts the acquisition of second homes by non-nationals, the same exception granted in the favour of Malta following its accession in 2004 and restrictions regarding the acquisition of real estate on Åland Islands in Finland. The second category of restrictions are those that arise out of accession to the EU and are limited in duration.

\subsection{New Member States in the EU and their transitional periods}

More recent enlargements of the European Union in 2004 (Cyprus, the Czech Republic, Estonia, Hungary, Latvia, Lithuania, Malta, Poland, Slovakia and Slovenia), in 2007 (Bulgaria and Romania) ${ }^{35}$ and 2013 (Croatia) gave the possibility to new Member States to keep the transitional restrictions on the acquisition of agricultural land following their accession to the EU for a certain period of time. The reason behind this concession of the Union was to enable the new Member States to

32 See the land report for Sweden of the European Land Registry Network [https://www.elra.eu/contact-point-contribution/sweden/legal-restrictions-6/], accessed on 6 April 2020

33 Greece prohibited the purchase of an agricultural property exceeding 25 hectares without a prior approval of the authorities, op.cit. land report for Greece, note 30

34 For example, the French law prescribes an obligation to report such transactions to the Ministry of Economy, while Croatian transactions need to be reported to the Croatian National Bank. See the Handbook for Real Estate Transactions, Deloitte Legal, 2017, [https://www2.deloitte.com/content/ dam/Deloitte/global/Documents/Legal/ dttl-legal-deloitte-legal-handbook-for-real-estate-transactions.pdf ], accessed on 26 March 2020

35 More about transitional arrangements for the enlargements from 2004 and 2007 can be found here: European Union accession and land tenure data in Central and Eastern Europe, FAO, Land Tenure Policy Series, Rome 2006, p. 27 
adapt their internal systems to (substantially higher) land prices in the old Member States $^{36}$. The "grace period" that was given to new Member States varies from one country to another, as it was a matter of pre-accession negotiations led between each country separately and the Union. The restrictions mostly did not incorporate the renting of the land, which was already before the transitory period accessible to the EU nationals of other states as well as the nationals of the state in question ${ }^{37}$.

The 2004 wave of enlargement saw three different transitional arrangements regarding the real estate market in new Member States. The first possibility, that was negotiated by the Czech Republic, Hungary and Poland, referred to the prohibition of EU nationals from other Member States from the acquisition of secondary residences. The transitional period lasted five years after the accession. The second arrangement, agreed with the Czech Republic, Estonia, Hungary, Latvia, Lithuania and Slovakia, granted them with seven-year transition periods during which they were allowed to continue with restrictions on EU nationals acquiring agricultural and forest land. Hungary managed to negotiate even more favourable conditions, namely, that this restriction extends to not only foreign natural but also legal persons during the given period. On the other hand, Poland managed to negotiate the 12-year transition period for this arrangement ${ }^{38}$. These arrangements were to be reviewed by the EU after a certain time and then, if proven necessary, they could have been shortened or extended for up to three additional years. Upon the expiration of the three-year extension no further extension was possible. The third concession by the Union was given in a form of a general economic safeguard clause and it was applied to Slovenia. For up to seven years after its accession, the country was allowed to apply for authorization to take protective measures for its real estate market in the case of serious difficulties.

Hungary, Latvia, Lithuania and Slovakia had requested the extension of their transitional periods for another three years, while the Czech Republic, Malta, Cyprus, Slovenia and Estonia had not ${ }^{39}$. Since Poland had the longest transitional period of 12 years, it did not have the possibility to request the extension.

36 An overview of the trends in land sales and land prices in the accession countries can be found here: Swinnen, J.F.M.; Vranken, L., Land \& EU Accession, Review of the Transitional Restrictions by New Member States on the Acquisition of Agricultural Real Estate, Centre for European Policy Studies, Brussels, 2009, p. 35

$37 \quad$ Ibid., p. 15

38 More on the details of negotiations between the new member states and the EU can be found here: Mihaljek, D., Free Movement of Capital, the Real Estate Market and Tourism: A Blessing or a Curse for Croatia on Its Way to the European Union, p. 192, [http://www.ijf.hr/eng/EU3/mihaljek.pdf], accessed on 6 April 2020

39 EU Commission press release report: Frequently asked questions, Extension of transitional periods for the acquisition of agricultural land, 14 April 2011, MEMO/11/244, [https://ec.europa.eu/commis- 
In the 2007 wave of enlargement Bulgaria and Romania took the possibility to restrict the EU citizens from acquiring land for secondary residences (excluding those who are residing in the country) for five years, and from acquiring forest and agricultural land for seven years after the accession. These two countries did not have a possibility to request a prolongation of their transitory periods.

During its negotiation period preceding the accession to the EU, Croatia arranged for a seven-year grace period regarding the sale of its agricultural land to non-nationals. This transitional period will expire in June 2020, but it is expected that Croatia will, like other countries that accessed the EU from 2004 onwards, request an additional period of three years.

However, during the transitional period it became evident that, despite the prohibition of alien acquisition, the number of such transactions actually increased in comparison with the period before the accession. The reason behind it could be that national laws allowed for certain exceptions to the rule of prohibition. For example, the land sale to the foreigner was allowed if the buyer was married to a national of the country in question and was residing and farming in the country for certain time before the purchase ${ }^{40}$. Furthermore, in all countries except for Hungary it was possible to acquire land by setting up a company with the registered seat in those countries, even in the case that the founders did not have the citizenship of that country ${ }^{41}$, so the foreigners bypassed the regulations by purchasing land through locally registered companies or by local proxies ${ }^{42}$. In some countries in that period the grey area of transfer practices developed, such as "pocket contracts", which were one of the main mechanisms of land acquisition in Hungary ${ }^{43}$. These were contracts signed between a resident seller and a non-resident buyer that contained all the necessary details apart from the date of contract.

sion/ presscorner/detail/en/MEMO_11_244 ], accessed on 27 March 2020

40 For more details on these exceptions see: Table I, Legal restrictions on the acquisition of agricultural land in the NMS, Swinnen et al., op. cit. note 36, p. 5

${ }_{41}$ More on the exceptions acceptable in new Member States and particularly Slovakia can be found here: Bandlerova, A., Marišova, E., Schwarcz, P., Ownership and use relationships to agricultural land in Slovakia after the EU accession, Proceedings of the international conference on "Entrepreneurship in Rural Areas - EU business law I, Pol'ný Kesov, 12-13 May 2011, p. 20

42 For example, although foreigners were restricted from buying agricultural land in Poland until 2016, more than 200,000 ha of land was bought by Dutch, Danish, German and British companies, with the help of "fake" buyers - locals willing to help who were hired to buy the land and transfer it to the foreign company when it became possible. See: op.cit., Land Concentration, Land Grabbing and People's Struggles in Europe, note 22, p.18

43 It is estimated that around 1 million ha of agricultural land has been acquired by foreign companies in this period through "pocket contracts". Ibid., p. 133 
They would subsequently be dated and registered in the land books after such registration would be allowed.

After the transitional period expired in 2011, all countries except for the Czech Republic applied for and were granted an extension until 2014. The extended transitional measures expired finally in 2014 (for Poland in 2016).

\subsection{Post-transitional periods and "new measures" to preserve the status quo}

After their transitional periods expired, some of the Member States still tried to preserve the effect of the restrictive measures and found new ways to efficiently prevent the agricultural land from the takeover by foreign investors ${ }^{44}$. Their new land laws changed the restrictions that were addressed by the Accession Treaties, but they introduced some new measures aiming at preserving the status quo in regard to alien acquisition of the agricultural land. Romania, for example, adopted in 2014 a new law on land acquisitions that granted the pre-emption right (in the following order) to co-owners, tenants, neighbouring owners and the State of Romania ${ }^{45}$. The procedure of offering the land to certain groups of potential buyers with pre-emption right was also introduced in Slovakia in 2014. If the intended sale resulted in none of the groups exercising their pre-emption right to buy, the land could then have been offered to a natural or legal person from another EU country. However, to be eligible for that, they needed to already have a permanent residence in Slovakia for at least 10 years ${ }^{46}$. This provision almost entirely prevented the foreign investments into Slovak land market. Poland also introduced new measures upon the expiration of its temporary restrictions, that were similar in nature to those in Romania. It further limited the surface on the agricultural land that can be bought and ordered that all transactions should be submitted for approval to the national agricultural property agency ${ }^{47}$. In 2014 Latvia set the new criteria for the eligibility of agricultural land buyers, following the expiration of their temporary measures like other countries did. Latvia made the approval of the

44 During this period an important role was played by the general public, who put pressure on their national governments to prevent the foreigners from "grabbing" their land. Poland saw nationwide mass protests on the streets that lasted four months. See Ciaian, P.; Drabik, D.; Falkowski, J.; Kancs, D., New regulations governing land sales in Central and Eastern Europe: Imposing restrictions via particularized institutions, European Commission, JRC Technical Reports, 2017, p. 16

45 For a more thorough analysis regarding the specific provisions of this law, see Table 1 in: Ciaian, P.; Falkowski, J.; Drabik, D.; Kancs D., New regulations governing land sales in Central and Eastern Europe. Moving towards a limited-access order? In Market Impacts of New Land Market Regulations in Eastern EU Member States, Economics and Econometrics Research Institute Research Paper Series No 02/2016, ISSN:2031-4892

46 Ibid., p. 8

47 Ibid. 
foreigners' land acquisition conditional on whether the buyer is registered for the economic activity, whether he had received direct payments under the Common Agricultural Policy, had no tax debts and gave a written statement confirming he would start with the agricultural activities within a certain time after the acquisition. Legal entities had to fulfill additional conditions, among which was that at least one of the owners or a permanent employee has professional education in agriculture $^{48}$. The surface of the land available through these measures was also limited to a maximum of 2000 hectares in total. Notwithstanding the objections of the European Commission ${ }^{49}$ to the land policy in Latvia, the Latvian Parliament passed a new law in 2017 that even further increased the level of restrictions for the foreigners. New provisions obliged all persons acquiring the land to speak the Latvian language ${ }^{50}$ and they reinforced pre-emption rights of certain groups.

\section{REACTIONS FROM THE EU INSTITUTIONS}

EU institutions gave their opinion on the legal approach of Member States regarding the foreign land acquisitions on several occasions during the last decade. The Economic and Social Committee in its opinion from 2015 recognized that the fact that in some countries there are restrictions regarding the acquisition of agricultural land, and in some not, is leading to disparities between Member States. The Committee called on the European Parliament and the Council to "discuss whether the free movement of capital in respect of the alienation and acquisition of agricultural land and agribusinesses should be guaranteed, particularly in relation to third countries, but also within the EU"51. The European Parliament issued a study on the extent of the farmland grabbing in the EU in 2015, followed by a report on facilitating the access to land for farmers in 2016. The Parliament also requested from the Commission to clarify the permitted land market regulation mechanisms under the European law. In its study from 2015 it called on

$48 \quad$ Ibid., p. 11

49 Commission raised objectives towards land sale policies of Bulgaria, Hungary, Latvia, Lithuania and Slovakia in May 2016, see the Commission press release, [https://ec.europa.eu/commission/presscorner/ detail/en/IP_16_1827], accessed on 28 March 2020

50 The required level of knowledge is B2 - upper-intermediate level of proficiency. Although the Act went through several amendments (the latest in February 2020), this provision remained in force. It applies not only to natural persons, but also to responsible persons in legal entities. For more details see the Latvian Act on Land Privatization in Rural Areas, consolidated version, available here: [https://likumi. lv/ta/id/74241\#p28], accessed on 3 April 2020. Media reports on law amendments, Public Broadcasting of Latvia, available here: [https://eng.lsm.lv/article/economy/economy/saeima-passes-law-restricting-farmland-sales-to-those-with-latvian-language.a236865/], accessed on 3 April 2020

51 Opinion of the European Economic and Social Committee of 21.1.2015 on Land grabbing - a warning for Europe and a threat to family farming (own-initiative opinion), points 1.8 and 1.9, Official Journal, C 242/15 
the CJEU to "show more flexibility in its interpretation of national measures that can be undertaken to restrict the free movement of capital according to justifiable political objectives" 52 .

\subsection{Infringement procedures by the EU Commission}

Although some authors argue that similar restrictions can be found also in the "old" EU Member States legislation ${ }^{53}$, the European Commission found the measures that countries introduced after their transitory periods have expired disputable and in March 2015 formally requested from these States to submit their observations on the national provisions regarding the land acquisition. The Commission found that several norms could potentially "leave room for discriminatory treatment of investors from other Member States". The Commission further assessed that Bulgaria, Hungary, Lithuania and Slovakia's national laws contained "several provisions which, under EU law, may be considered to restrict the free movement of capital and freedom of establishment" ${ }^{54}$. The concerning provisions included "a residence requirement in the given country, restrictions on persons without a local residence or previous local business activities, various restrictions on persons lacking professional knowledge, [...], as well as legal uncertainty related to the prior approval of sales contracts ${ }^{5}$. These letters of formal notice, by which the Commission required an answer from the Member States within 2 months, were the first stage of the EU law infringement process pursuant to the Article 258 of the TFEU. Only a month later, the same procedure was started against Latvia ${ }^{56}$. In both cases the Commission stated that, although the Member States are permitted to set their own legal framework to support rural development, these measures "must be in line with EU law".

Following these events, in May 2016 the Commission has formally requested all five countries to amend their legislation and bring it into line with the EU law within another two months. According to the press release published on behalf of the Commission, the Commission's "main concern in Bulgaria and Slovakia

52 Extent of Farmland Grabbing in the EU, a Study of DG for Internal Policies, Policy Department B: Structural and Cohesion Policies, p. 58, May 2015, IP/B/AGRI/IC/2014-069, PE 540.369, [https://www.europarl.europa.eu/RegData/etudes/STUD/2015/540369/IPOL_STU(2015)540369_ EN.pdf], accessed on 31 March 2020

53 Ciaian et al., op.cit. note 45, p. 12 and further

54 Press release of the European Commission from the 26 March 2015, IP/15/4673, [https://ec.europa. eu/commission/presscorner/detail/en/IP_15_4673], accessed on 23 March 2020

55 Ibid.

56 Press release of the European Commission from the 29 April 2015, IP/15/4877, [https://ec.europa.eu/ commission/presscorner/detail/EN/IP_15_4877], accessed on 23 March 2020 
is that buyers must be long-term residents in the country, which discriminates against other EU nationals. Hungary has a very restrictive system which imposes a complete ban on the acquisition of land by legal entities and an obligation on the buyer to farm the land himself. In addition, as in Latvia and Lithuania, buyers must qualify as farmers. While the Commission agrees that national authorities should be able to properly regulate farm land markets to maintain such land in agricultural use and promote local development, it found a number of these measures excessively restrictive and discriminatory in terms of attracting investment in rural development." 57

However, notwithstanding this warning of the Commission and some minor amendments to their land sale provisions, these countries did not entirely amend their legislation. Still, the Commission closed the case regarding Lithuania on 7 March 2019 and regarding Slovakia on 10 October 2019. The cases regarding Hungary, Latvia and Bulgaria still remain open ${ }^{58}$. In the meantime the Commission started another procedure against Hungary for alleged unlawful termination of foreign investors' usufruct rights related to agricultural land, which led to a referral to the Court of Justice of the EU on the ground of violation of principles of free movement of capital and freedom of establishment. In two separate proceedings ${ }^{59}$ the CJEU found that Hungary has failed to fulfill its obligations arising from the EU law - principle of the free movement of capital and it infringed the right to property guaranteed by the Charter of Fundamental Rights of the EU by depriving the nationals of other Member States of their rights of usufruct on agricultural land ${ }^{60,61}$.

$57 \quad$ EU Commission press release, op.cit. note 49

58 As of 5 April 2020

59 Joined Cases C52/16 (SEGRO Kft.v Vas Megyei Kormányhivatal Sárvári Járási Földhivatala) and C113/16 (Günther Horváth v Vas Megyei Kormányhivatal), ECLI:EU:C:2018:157, and the separate case C-235/17 (European Commission v Hungary), ECLI:EU:C:2019:432

60 The Court has found that, on the grounds of various forms of Hungarian policy of preventing the foreigners from acquisition of property on agricultural land, many of them have resorted to acquiring different forms of land usage, such as usufruct. This practice led to the situation in which the beneficiaries of usufruct rights were mainly non-nationals. Hence, the law affected mostly them, which the Court deemed a restriction on the free movement of capital and indirect discrimination based on the usufructuary's nationality or on the origin of the capital. See the press release of the CJEU No. 25/18 from 6 March 2018: [https:/curia.europa.eu/jcms/ upload/docs/application/pdf/2018-03/cp180025en.pdf], accessed on 6 April 2020 and the press release No. 65/19 from 21 May 2019 [https://curia.europa.eu/ jcms/upload/docs/application/pdf/2019-05/cp190065en.pdf], accessed on 6 April 2020

61 More on Hungarian economic patriotism and reasoning behind their agricultural policies can be found in Rauchegger, C., Wallerman, A., The Eurosceptic Challenge: National Implementation and Interpretation of EU Law, Hart Publishing, 2019, p. 103 and further 
Another example of continuing restrictions on foreign investors' land acquisition is Latvia. Although the EU Commission opened an infringement procedure against Latvia already in 2015, urging for changes in the then Latvian law on purchase of agricultural land, the country did not entirely adhere to the Commission's request. Namely, they abolished some of the challenged provisions, but introduced a new one - criterion of obligatory proficiency in Latvian language for the prospective land buyers. In the following years, the Commission did not officially refer Latvia to the CJEU, nor has it closed the case against it. The Commission argues that for the time being "it is more appropriate to continue the discussion with the Latvian government outside the formal infringement procedure" ${ }^{62}$.

\subsection{EU Commission Communication on the acquisition of farmland}

Having noticed that "new" Member States are facing challenges to comply with the EU internal market rules in relation to their agricultural land policies and that these difficulties did not come to an end even long after the expiration of their transitory periods, in 2017 the Commission adopted an Interpretative Communication on the Acquisition of Farmland and European Union Law ${ }^{63}$. With this document the Commission is attempting to instruct the Member States on how to protect their agricultural land and bring their national provisions in line with the EU legal framework. The Commission recognized that cross-border land acquisition should be assessed both from the perspective of the free movement of capital (while the right to acquire, use or dispose of agricultural land falls under the principle of free movement of capital ${ }^{64}$ ) and the freedom of establishment perspective (if the investments in farmland are serving agricultural entrepreneurial activities). The Commission further enlisted certain objectives that were recognized by the CJEU in its cases and that are, from the viewpoint of the CJEU, acceptable as grounds for restrictions in cross-border land acquisitions ${ }^{65}$. These objectives include: increasing the size of land holdings to prevent land speculation, preserving agricultural communities to sustain and develop viable agriculture on the basis of social and land planning considerations, preserving a traditional form of farming

62 Commission's reasoning given in 2019 in the proceeding in front of the European Ombudsman, initiated by a Danish farmer against Latvia, Case 34/2019/MOM, [https:/www.ombudsman.europa.eu/ $\mathrm{hr} /$ decision/en/113027], accessed on 8 April 2020

63 Commission Interpretative Communication on the Acquisition of Farmland and European Union Law, Official Journal C 350/05

64 There are decisions of the CJEU that confirm that the acquisition of the agricultural land falls under the free movement of capital principle. See case C-370/05 Anklagemyndigheden v Uwe Kay Festersen, ECLI:EU:C:2007:59 and case C-452/01 Ospelt and Schloessle Weissenberg Familienstiftung, ECLI:EU:C:2003:493

65 More on these objectives can be found here: EU Commission Communication, op.cit., note 63, p. 7 
(where the land owner is also a farmer), planning a permanent population and an economic activity independent of the tourism sector in certain regions, protecting military areas from being exposed to risks. It is important to stress that this list of objectives is not closed, as acceptable objectives arise out of ad hoc approach of the CJEU and its deciding on a specific set of circumstances in a single case. However, it is pointed out that each particular restriction needs to be assessed in-depth in regard to its proportionality.

Finally, the Commission enlisted some of the most common restrictions in land acquisition models throughout the Union, and assessed them through the scope of the EU law ${ }^{66}$.

- Prior authorization requested for the transfer of agricultural land - can be acceptable in some circumstances, but must not grant discretionary powers that can lead to arbitrary use by competent authorities. All persons affected must have access to legal redress.

- If having "sufficient connection with the commune" is the prerequisite for the approval of the land transfer - this measure is disproportionate and as such not acceptable in national legal frameworks ${ }^{67}$.

- Pre-emption rights in favour of certain categories of buyers (tenant farmers) can be justified, and it is a more acceptable measure than the prohibition of acquisition for the persons who are not farmers. The Commission also assessed the privilege for acquisition in favour of local buyers and concluded that this might often constitute covert discrimination on the grounds of nationality while it is notorious that most of the locals are likely to be nationals of the state in question.

- Self-farming obligation as a prerequisite for the acquisition of agricultural land is not accepted as an appropriate measure, also the CJEU founds it disproportionate. If the objective of the state is to keep the land in agricultural use, this can be achieved by making the purchase conditional on the written statement of the buyer that the land will be kept in use for these purposes. The Commission also found that the obligation to personally engage in agricultural work could collide with the freedom to conduct a business, as guaranteed by the EU Charter of Fundamental Rights ${ }^{68}$. It also precludes legal entities from acquiring the ownership of the land, which is a restriction of the free movement of capital and freedom of establishment.

\footnotetext{
66 Ibid., p. 8

67 Joined Cases Eric Libert and Others v Gouvernement flamand (C197/11) and All Projects \& Developments NV and Others $v$ Vlaamse Regering (C203/11), ECLI:EU:C:2013:288

68 EU Commission Communication, op.cit. note 63, p. 11
} 
- Professional qualifications in agriculture as a prerequisite for buying agricultural land is a disproportionate measure. The Commission explains that none of the Member States have a "farmer" as a regulated profession that would require a certain level of education, and Member States so far have not proven why a certain level of qualification would be a conditio sine qua non for the acquisition of the agricultural land.

- The condition of having a registered residence in the vicinity of the land that is an object of the purchase ${ }^{69}$ was also ruled out as incompatible with the internal market - the free movement of capital. Such a requirement would also collide with the right to choose a residence and move freely within the territory of the Member States, which is a right guaranteed by the TFEU (Article 21) and the Charter of Fundamental Rights of the EU (Article 45). Here the Commission drew a parallel with the requirement of speaking a language of the country in question (as seen in the Latvian legislation) and states that such a requirement would "meet very similar objections" as to its discriminatory effect.

- Limited surface of agricultural land available for purchase per investor is a restriction to the free movement of capital, whereby acquisition caps on the national level can be acceptable in certain circumstances. As with other measures, the justification and proportionality of this measure needs to be well examined to assess whether it can be replaced by different and more moderate measures.

Although it seems that Commission defined many national property acquisition provisions as disproportionate and as such not compatible with the EU law, it did say under which conditions certain measures could be deemed acceptable. In the final remark the Commission concludes: "The main condition is that the objectives are clearly set out and that the instruments chosen are proportionate to these objectives in the sense that they do not go beyond what is necessary and that they are not discriminatory" ${ }^{\prime \prime 0}$.

\section{PROPORTIONALITY TEST OF THE NATIONAL MEASURES}

The principle of proportionality (together with the principle of subsidiarity) is one of the general principles of European law. It is rooted in the Article 5 of the TEU and the Protocol No.2 (to the TFEU on the application of the principles of subsidiarity and proportionality) and further developed in the practice of CJEU. This principle applies both to acts of the European institutions and Member States.

\footnotetext{
69 Case C-370/05, op.cit. note 64, par. 44

70 EU Commission Communication, op.cit. note 63, p. 13
} 
However, it is applied partially differently at these two levels $s^{71}$. From the Member States' side, it requires that each national measure is based on a fair assessment. The Treaties allow restrictions on foreign investments into agricultural land, but under the condition of proportionality of such restrictive measures. National measures that are restricting fundamental freedoms, such as the freedom of movement of capital, can only be justified if certain conditions are met: a measure must be appropriate, which means that it is suitable to pursue a certain legitimate objective, it must be necessary, meaning that it must not exceed the necessary minimum to achieve the objective and there are no other less restrictive means available to pursue the same objective. It also needs to be reasonable (proportionality stricto sensu), whereby the comparison is not made between more possible measures, but between the effect of a certain measure and the benefit that the measure is aiming to bring ${ }^{72}$. Moreover, the assessed measure must not be discriminatory. It is important to notice that the CJEU has already ruled that a national measure cannot be deemed disproportionate only because other Member States have adopted less strict measures ${ }^{73}$.

The principle of proportionality is a tool by which the Member States can and are even obliged to assess whether the measure aiming at pursuing their national legitimate objective is acceptable from the EU standpoint. However, keeping in mind that national states tend to find any possible way to protect the national interests, and knowing that "the application of the proportionality principle in the EU can be characterised as a balancing act [...] between the levels of government, between the remaining responsibilities of the Member States and integration, and between policies and individual rights" ${ }^{74}$, it is inevitable that the European Union starts to practice a more rigorous control of national restrictive measures if it wishes to maintain the functioning internal market.

\section{CONCLUSION}

The cornerstone of the EU is the internal market, established through the Union's basic market freedoms and the prohibition of discrimination on the basis of nationality. Any restriction on the acquisition of the property by non-nationals is incompatible with the idea of the internal market. Countries aspiring to join the EU

\footnotetext{
71 More on the proportionality in acts of the Member States, as well as the „least restrictive means" test applicable for these acts can be found here: Sauter, W., Proportionality in EU Law: A Balancing Act?, Cambridge Yearbook of European Legal Studies, vol. 15, 2013, p. 452

72 Kellerbauer, M.; Klamert, M.; Tomkin, J., Commentary on the EU Treaties and the Charter of Fundamental Rights, Oxford University Press, 2019, p. 474

73 Case C-384/93 Alpine Investments BV v Minister van Financiën, ECLI:EU:C:1995:126, par. 51

74 Sauter, op.cit., note 71, p. 466
} 
need to remove any remaining barriers to the free mobility of trade, capital, labour and enterprise with the other members of the Union. A well-established internal market requires a functioning property market where real estate can be freely purchased and sold, otherwise the free movement of people and capital is hindered. Moreover, the principle of non-discrimination on grounds of nationality is inseparable from all fundamental freedoms. In the last decades Member States have gone through many changes in their national legal systems regulating the acquisition of the real estate property by the non-nationals. Certain categories of real estate are precluded from acquisition based on the Treaties (Denmark, Malta, Åland Islands), certain are still under transitional regimes (agricultural land in Croatia). However, there is still a specific category of covert discriminatory measures that can be found in "new" Member States since the expiration of their transitional periods. Even though the Union has addressed this problem on several occasions, and most importantly, started an infringement process against some of them, it cannot be concluded that all States have unconditionally adjusted their legislative framework to the European law. In order to help the Member States comply with the requirements of the EU law, the EU Commission has issued a document that compiled the most common measures and assessed their suitability for pursuing the legitimate objectives of the States. The mechanism advised by the Commission is the test of proportionality. It is yet to be seen in the following years whether the Member States will adhere to these requests.

Although this paper has shown that there have been cases of restrictions regarding different types of property, this has changed under the influence of EU law in the last decades. Nowadays restrictions refer mostly to agricultural land (which by definition in some countries includes the forest land as well). And as much as it is obvious that certain Member States persistently try to avert the foreign takeover of their land and they avoid fully complying with the internal market, it is also quite apparent that the Union is relatively tolerant towards such national policies (as for example with Latvia). The Union's hesitancy to proceed with some infringement procedures might be politically motivated, but it surely gives a message to other Member States that different rules apply for different subjects on the internal market. It is only a matter of time when other, compliant Member States will legitimately raise an objection regarding that, and that moment might be the end of the internal market as we know it. 


\section{REFERENCES}

\section{BOOKS AND ARTICLES}

1. Akkermans, B.; Ramaekers, E., Article 345 TFEU (ex Article 295 EC), Its Meanings and Interpretations, European Law Journal, vol. 16, no. 3, 2010

2. Bandlerova, A., Marišova, E., Schwarcz, P., Ownership and use relationships to agricultural land in Slovakia after the EU accession, Proceedings of the international conference on "Entrepreneurship in Rural Areas - EU business law I, Pol'ný Kesov, 12-13 May 2011

3. Ciaian, P.; Drabik, D.; Falkowski, J.; Kancs, D., New regulations governing land sales in Central and Eastern Europe: Imposing restrictions via particularized institutions, European Commission, JRC Technical Reports, 2017

4. Ciaian, P.; Falkowski, J.; Drabik, D.; Kancs D., New regulations governing land sales in Central and Eastern Europe. Moving towards a limited-access order? In Market Impacts of New Land Market Regulations in Eastern EU Member States, Economics and Econometrics Research Institute Research Paper Series No 02/2016, ISSN:2031-4892

5. European Union accession and land tenure data in Central and Eastern Europe, FAO, Land Tenure Policy Series, Rome, 2006

6. Josipović, T., Pravni promet nekretnina u Europskoj Uniji, Prilagodba hrvatskog pravnog poretka europskom, Narodne Novine, Zagreb, 2003

7. Kellerbauer, M., Klamert, M., Tomkin, J., Commentary on the EU Treaties and the Charter of Fundamental Rights, Oxford University Press, 2019

8. Mataczyński, M., What Did the European Community Founders Actually Mean by Saying That the Treaties Shall in No Way Prejudice the Rules in Member States Governing the System of Property Ownership? Analysis of Article 345 TFEU, Adam Mieckiewicz University Law Review, vol. 4, 2014

9. Mišćenić, E., Europsko privatno pravo, Opći dio, Školska knjiga, Zagreb, 2019

10. Rauchegger, C., Wallerman, A., The Eurosceptic Challenge: National Implementation and Interpretation of EU Law, Hart Publishing, 2019

11. Real Property Law and Procedure in the European Union, General Report, European University Institute (EUI) Florence / European Private Law Forum / Deutsches Notarinstitut (DNotI) Würzburg, 31.5.2005

12. Sauter, W., Proportionality in EU Law: A Balancing Act?, Cambridge Yearbook of European Legal Studies, vol. 15, 2013

13. Swinnen, J.F.M.; Vranken, L., Land \& EU Accession, Review of the Transitional Restrictions by New Member States on the Acquisition of Agricultural Real Estate, Centre for European Policy Studies, Brussels, 2009

\section{LIST OF NATIONAL REGULATIONS, ACTS AND COURT DECISIONS}

1. The Constitution of the Republic of Bulgaria, Prom. SG 56/13 Jul 1991, amend. SG 85/26 Sep 2003, SG 18/25 Feb 2005, SG 27/31 Mar 2006, SG 78/26 Sep 2006 - Constitutional Court Judgment No.7/2006, SG 12/6 Feb 2007 
2. The Constitution of the Republic of Croatia, Official Gazette 56/90, 135/97, 08/98, 113/00, $124 / 00,28 / 01,41 / 01,55 / 01,76 / 10,85 / 10,05 / 14$

3. The Constitution of the Republic of Slovenia, Official Gazette RS Nos. 33/91-I, 42/97, 66/2000, 24/03, 69/04, 68/06, 47/13, and 75/16

4. The Constitution of Romania, Official Gazette Part I No.233 of 21 November 1991 with the amendments in Part I, No.758 of 29 October 2003

5. The Belgian Constitution, Belgian Official Gazette of 31 January 2014 with the amendments from 29 November 2017

6. The Constitution of the Republic of Estonia, RT 1992, 26, 349, amended by RT I 2003, 29, 174, amended by RT I 2003, 64, 429, amended by RT I 2007, 33, 210, amended by RT I, 27.04.2011, 1

7. The Czech Charter of Fundamental Rights and Freedoms, Ústavní zákon č. 2/1993 Sb. ve znění ústavního zákona č. 162/1998 Sb.

8. The Constitution of the Republic of Slovakia, Official Gazette 460/1992 Zb., 244/1998, 9/1999, 90/2001, 140/2004, 323/2004, 463/2005, 92,2006, 210/2006, 100/2010, 356/2011, 232/2012, 161/2014, 306/2014, 427/2015, 44/2017, 71/2017, 137/2017, 40/2019, 99/2019

9. Act on Ownership and Other Real Rights of the Republic of Croatia, Official Gazette 91/1996, 68/1998, 137/1999, 22/2000, 73/2000, 114/2001, 79/2006, 141/2006, $146 / 2008,38 / 2009,153 / 2009,90 / 2010,143 / 2012,152 / 2014$

10. Nature Protection Act of the Republic of Croatia, Official Gazette 80/13, 15/18, 14/19, $127 / 19$

11. Act on Protection and Preservation of Cultural Heritage, Official Gazette 69/1999, $151 / 2003,100 / 2004,87 / 2009$, 88/2010, 61/2011, 25/2012, 136/2012, 157/2013, $152 / 2014,98 / 2015,44 / 2017,90 / 2018,32 / 2020$

\section{EU LAW}

1. Consolidated version of the Treaty on the Functioning of the European Union, Official Journal C 326, 26.10.2012

2. Charter of Fundamental Rights of the European Union, Official Journal C 326, 26.10.2012

3. Regulation (EU) No 492/2011 of the European Parliament and of the Council of 5 April 2011 on freedom of movement for workers within the Union, Official Journal L 141/1

4. Opinion of the European Economic and Social Committee of 21.1.2015 on Land grabbing - a warning for Europe and a threat to family farming (own-initiative opinion), Official Journal, C 242/15

5. Commission Interpretative Communication on the Acquisition of Farmland and European Union Law, Official Journal C 350/05

\section{CJEU CASE LAW}

1. Case C-182/83, Fearon \& Company Limited v Irish Land Commission, ECLI:EU:C:1984:335

2. Case C-302/97, Konle v Republic of Austria, ECLI:EU:C:1999:271 
3. Case C-105/12, Essent and Others, ECLI:EU:C:2013:677

4. Case C-305/87 Commission v Greece, ECLI:EU:C:1989:218

5. Joined Cases C52/16 (SEGRO Kft.v Vas Megyei Kormányhivatal Sárvári Járási Földhivatala) and C113/16 (Günther Horváth v Vas Megyei Kormányhivatal), ECLI:EU:C:2018:157

6. Case C-235/17 (European Commission v Hungary), ECLI:EU:C:2019:432

7. Case C-370/05 Anklagemyndigheden v Uwe Kay Festersen, ECLI:EU:C:2007:59

8. Case C-452/01 Ospelt and Schloessle Weissenberg Familienstiftung, ECLI:EU:C:2003:493

9. Joined Cases Eric Libert and Others $v$ Gouvernement flamand (C197/11) and All Projects \& Developments NV and Others $v$ Vlaamse Regering (C203/11), ECLI:EU:C:2013:288

10. Case C-384/93 Alpine Investments BV v Minister van Financiën, ECLI:EU:C:1995:126

\section{WEBSITE REFERENCES}

1. European Convention on Human Rights, Council of Europe [https://www.echr.coe.int/ Documents/Convention_ENG.pdf], accessed on 14 March 2020

2. The Constitution of the Grand Duchy of Luxembourg [http://www.legilux.public.lu/eli/ etat/leg/recueil/constitution/20191214], accessed on 27 March 2020

3. Land Concentration, Land Grabbing and People's Struggles in Europe, published by the Transnational Institute for European Coordination Via Campesina and Hands Off the Land Network, June 2013, [https://www.fian.be/IMG/pdf/2013_06_Land_in_Europejun2013_final.pdf\#page=128], accessed on 2 April 2020

4. Land report for Spain of the European Land Registry Network: [https://www.elra.eu/contact-point-contribution/spain/legal-restrictions-10/], accessed on 6 April 2020

5. Land report for Greece on the European Land Registry Network: [https://www.elra.eu/contact-point-contribution/greece/legal-restrictions-5/] , accessed on 6 April 2020

6. Land report for Lithuania on the European Land Registry Network [https://www.elra.eu/ contact-point-contribution/lithuania/legal-restrictions-18/], accessed on 6 April 2020

7. Land report for Sweden of the European Land Registry Network [https://www.elra.eu/contact-point-contribution/sweden/legal-restrictions-6/], accessed on 6 April 2020

8. Restrictions on Acquisition of Immovables Act, RT I, 23.02.2012, 11, [https://www.riigiteataja. ee/en/eli/ee/514112013013/consolide/current], accessed on 30 March 2020

9. Swinnen, J.; Van Herck, K.; Vranken L., Land Market Regulations in Europe, LICOS Centre for Institutions and Economic Performance, KU Leuven, Discussion Paper, No. 354, p. 10 and further, [https:/www.econstor.eu/bitstream/10419/126507/ 1/797825487.pdf], accessed on 3 April 2020

10. Handbook for Real Estate Transactions, Deloitte Legal, 2017, [https://www2.deloitte.com/ content/dam/Deloitte/global/Documents/Legal/dttl-legal-deloitte-legal-handbook-for-real-estate-transactions.pdf], accessed on 26 March 2020

11. Mihaljek, D., Free Movement of Capital, the Real Estate Market and Tourism: A Blessing or a Curse for Croatia on Its Way to the European Union, p. 192, [http://www.ijf.hr/eng/EU3/ mihaljek.pdf], accessed on 6 April 2020 
12. EU Commission press release: Frequently asked questions, Extension of transitional periods for the acquisition of agricultural land, 14 April 2011, MEMO/11/244, [https://ec.europa.eu/ commission/presscorner/detail/en/MEMO_11_244], accessed on 27 March 2020

13. Press release of the European Commission from the 26 May 2016: [https://ec.europa.eu/ commission/presscorner/detail/ en/IP_16_1827], accessed on 28 March 2020

14. Press release of the European Commission from the 26 March 2015, IP/15/4673, [https:// ec.europa.eu/commission/presscorner/detail/en/IP_15_4673], accessed on 23 March 2020

15. Press release of the European Commission from the 29 April 2015, IP/15/4877, [https:// ec.europa.eu/commission/presscorner/detail/EN/IP_15_4877], accessed on 23 March 2020

16. Latvian Act on Land Privatization in Rural Areas, consolidated version, [https://likumi.lv/ta/ id/74241\#p28], accessed on 3 April 2020

17. Media reports on law amendments, Public Broadcasting of Latvia, available here: [https:// eng.lsm.lv/article/economy/economy/saeima-passes-law-restricting-farmland-sales-tothose-with-latvian-language.a236865/ ], accessed on 3 April 2020

18. Press release of the CJEU No. 25/18 from 6 March 2018: [https://curia.europa.eu/jcms/ upload/docs/application/pdf/2018-03/cp180025en.pdf], accessed on 6 April 2020

19. Press release No. 65/19 from 21 May 2019 [https://curia.europa.eu/jcms/upload/ docs/application/pdf/2019-05/cp190065en.pdf], accessed on 6 April 2020

20. Case 34/2019/MOM of the European Ombudsman, [https://www.ombudsman.europa.eu/ $\mathrm{hr} /$ decision/en/113027], accessed on 8 April 2020

21. Extent of Farmland Grabbing in the EU, a Study of DG for Internal Policies, Policy Department B: Structural and Cohesion Policies, p. 58, May 2015, IP/B/AGRI/IC/2014-069, PE 540.369, [https://www.europarl.europa.eu/RegData/etudes/STUD/2015/ 540369/IPOL_ STU(2015)540369_EN.pdf], accessed on 31 March 2020 